\title{
Ph, Kadar Fenolat Total, Dan Aktivitas Antioksidan Kefir Susu Kambing Yang Ditambahkan Seduhan Kopi Robusta (Skr)
}

\author{
Dwi Pratama, Putri Dian Wulansari, Nurul Frasiska \\ Program Studi Peternakan, Fakultas Pertanian, Universitas \\ Perjuangan Tasikmalaya \\ Kode Pos, Jl. Peta No.177, Kahuripan, Kec. Tawang, Tasikmalaya, Jawa Barat \\ 46115 \\ *Corresponding E-mail: putridian@unper.ac.id
}

\begin{abstract}
ABSTRAK
Kefir susu kambing dengan penambahan seduhan kopi robusta (SKR) dapat meningkatkan kualitas fungsional, karena kandungan antioksidan yang dimilikinya. Tujuan penelitian ini adalah untuk mengetahui pengaruh penambahan SKR pada kefir susu kambing dan menentukan level persentasepemberian SKR yang maksimal. Penelitian dilakukan secara eksperimental menggunakan Rancangan Acak Lengkap dengan 5 perlakuan dan 5 ulangan. Level penambahan SKR pada pembuatan kefir sebanyak $0 ; 5 ; 10 ; 15$ dan $20 \%$. Parameter yang dianalisis meliputi $\mathrm{pH}$ diukur menggunakan $\mathrm{pH}$ meter, kadarpolifenol total menggunakan reagenFolin-Ciocalceu, dan aktivitas antioksdian ditetentukan dengan metode DPPH. Data yang diperoleh dianalisis menggunakan uji ANAVA, dan jika berpengaruh nyata atau siginifikan dilanjut menggunakan uji beda Tukey. Hasil penelitian menunjukan bahwa penambahan SKR terhadap nilai $\mathrm{pH}$ sangat berpengaruh nyata $(\mathrm{P}<0.05)$, kadar polifenol total dan aktivitas antioksidan mengalami peningktan dibandingkan perlakuan P0 atau kontrol. Semakin tinggi penambahan SKR dalam pembuatan kefir maka semakin tinggi pula nilai $\mathrm{pH}$ yang dihasilkan. Penambahan SKR sebanyak $20 \%$ menghasilkan kefir dengankadar $\mathrm{pH} 4.35$, nilai $\mathrm{pH}$ ini masih masuk standar $\mathrm{pH}$ susu fermentasi untuk susu fermentasi. Kadar polifenol total pada penelitian ini semakin meningkat dengan semakin banyaknya penambahan SKR. Penambahan SKR sebanyak 20\% menghasilkan kadar polifenol total sebesar $684.4686 \mathrm{mg} / \mathrm{L}$ lebihtinggi $70 \%$ dibandingkan control. Sampel kefir yang diperkaya 20\% SKR menunjukan nilai aktivitas antioksdian paling tinggi DPPH IC50 sebesar 554.3444. Kesimpulan penelitian ini bahwa penambahan SKR efektif meningkatkan aktivitas antioksdian, kadar fenolat total, dan $\mathrm{pH}$ kefir sesuai standar susu fermentasi.
\end{abstract}

Kata Kunci: Fermetasi, Fungsional, Seduhan kopi robusta, dan Susu kambing

\begin{abstract}
Goat milk kefir with the addition of robusta coffee brew (RCB) can improve functional quality, because of its antioxidant content. The purpose of this study was to determine the effect of adding SKR on goat's milk kefir and to determine the maximum percentage level of giving RCB. The research was conducted experimentally using a completely randomized design with 5 treatments and 5 replications. The level of adding SKR for kefir production is $0 ; 5 ; 10 ; 15$ and $20 \%$. The parameters analyzed included $\mathrm{pH}$ measured using a $\mathrm{pH}$ meter, total polyphenol levels using the Folin-Ciocalceu reagent, and antioxidant activity determined by the DPPH method. The data obtained were analyzed using the ANOVA test, and if it had a real or significant effect, it was
\end{abstract}


continued using the Tukey difference test. The results showed that the addition of SCR to the $\mathrm{pH}$ value had a significant effect $(\mathrm{P}<0.05)$, the total polyphenol content and antioxidant activity increased compared to the P0 treatment or control. The higher the addition of SKR in making kefir, the higher the $\mathrm{pH}$ value produced. The addition of $20 \%$ SCR produced kefir with a $\mathrm{pH}$ level of 4.35, this $\mathrm{pH}$ value is still included in the $\mathrm{pH}$ standard for fermented milk for fermented milk. The total polyphenol content in this study was increasing with the addition of SCR. The addition of $20 \%$ SCR resulted in a total polyphenol content of $684.4686 \mathrm{mg} / \mathrm{L}, 70 \%$ higher than control. The kefir sample enriched with $20 \%$ SKR showed the highest value of antioxidant activity of DPPH IC50 of 554.3444. The conclusion of this study is that the addition of SCR is effective in increasing the antioxidant activity, total phenolic content, and kefir $\mathrm{pH}$ according to the standard of fermented milk.

Keywords: Fermetation, Functional, Goat's milk, Robusta Coffee Brew 


\section{PENDAHULUAN}

Susu kambing merupakan susu dengan kandungan nutrien yang lengkap, karena memilki komposisi yang kompleks dibandingkan susu sapi. Kandungan Fluorine (F) didalam susu kambing terkandung 10-100 kali lebih banyak dibandingkan susu sapi (Haenlein,2004) Fluorine dapat berperan sebagai antiseptik yang dapat menekan perkembangan baketri dalam tubuh (Moeljanto \& Wiryanta, 2002). Butiran lemak susu kambing lebih kecil dari pada susu sapi yaitu berkisar 3,49 mikrometer. Sedangkan ukuran butiran susu sapi adalah 4,55 mikrometer.. Hal ini menyebabkan susu kambing dapat dicerna lebih mudah (Moeljanto \& Wiryanta, 2002).

Susu kambing memiki asam lemak jenuh yang tinggi $(69.9 \%)$ dan sisanya asam lemak tak jenuh $(30,1 \%)$. Asam lemak jenuh paling dominan adalah asam palmitat $(26,41 \%)$ dan asamoleat $(25,45 \%)$ (Sumarmono \& Sulistyowati, 2015). Susu kambing memiliki kandungan B12 yang tinggi dibandingkan dengan susu sapi, namun permasalahanya adalah kurangnya peminat (Efendi etal., 2019). Peptida yang dihidrolisisdari susu kambing menggunakan enzim bromelin diketahui memiliki aktivitas antibakteri dan antioksidan (Kusumaningtyas etal.,2016).

Pengolahan susu fermentasi adalah strategi pengolah susu yang menghasilkan produk fungisonal menurut Supartaet al. (2015). Jenis produk susu fermentasi beranekaragam diantara jenis kefir yang mengandung antioksidan (Supartaetal,2017) dan diperkuat dengan sifat fungsional yang lain yaitu bahwa adanya kandungan Bakteri Asam Laktat (Miwadaet al, 2011). Kefir memiliki warna dan rasa yang hampir sama dengan yogurt, yang dibuat menggunakan susu pasteurisasi menggunakan starter berupa butir kefir yaitu butiran-butiran putih atau krem yang berasal dari gabungan bakteri dan beberapa jenis khamir (Filan.Oet al.,2016).

Kefir memilki banyak manfaat salah satunya adalah antioksidan yang dapat melindungi badan dariradikalbebas dan kefir juga dapat menghambat pertumbuhan tumor lebih baik dibandingkan yogurt (Siwaranetal.,2016).Maka dari itu produk susu fermentasi sangat dibutuhkan masyarakat untuk kesehatan tubuh dan membiasakan supaya rutin meminum susu atau produk olahan peternakan. Kefir susu kambing mengandung Vitamin $\mathrm{E}$ yang tergolong antioksidan kuat. Aktivitas antioksidan kuat lainya salah satunya terdapat juga pada Kopi Robusta.

Kopi Robusta adalah kopi yang ditanam di dataran rendah sampai dengan 1000 MDPL pada suhu sekitar 20oC (Ridwansyah,2003). Indonesia merupakan salah satuprodusen Kopi Robusta dengan pangsa sebesar 20\% dari ekspor dunia, area penyebaran yaitu Sumatera (66\%), Jawa (12\%), Bali dan Nusa Tenggara (8\%), Sulawesi (7\%), Kalimantan (4\%), dan Maluku Papua (1\%) dengan luas areal kebun kopi mencapai 1.210.365 (Ditjenbun, 2013). Kopi robusta memiliki rasa yang khas serta berkhasiat tinggi melindungi badan dari radikal bebas karena adanya antioksidan dan mengandung polifenol yang dapat merangsang kinerja otak. Edwan Giovanucci salah satu peneliti dari Harvard University menjelaskan bahwa kopi meiliki antioksidan yang lebih tinggi dari kebanyakan sayur dan buah, dan kopi juga menjadi sumber antioksidan nomer satu dari semua jenis makanan (Mulato,2013). Pada kopi robusta memiliki standar $\mathrm{pH}$ yakni 7 (Herlina,2017). Pada penelitian ini kopi robusta akan diajadikan seduhan kopi robusta dicampur dengan susu kambing yang akan difermentasi. Dengan menggunakan proses seduhan kopi akan mempermudah proses homogenitas pada kedua bahan.

\section{MATERI DAN METODE}

\section{Metode Penelitian}

Metode penelitian ini menggunakan rancangan acak lengkap (RAL), dengan menggunakan 5 perlakuan.

TO :100\% susu kambing yang ditambahkan 0\% Seduhan Kopi Robusta (SKR)

T1 :95\% susu kambing yang ditambahkan 5\% Seduhan Kopi Robusta (SKR)

T2 :90\% susu kambing yang ditambahkan $10 \%$ Seduhan Kopi Robusta (SKR)

T3 :85\% susu kambing yang ditambahkan $15 \%$ Seduhan Kopi Robusta (SKR) 
T4 : 80\% susu kambing yang ditambahkan $20 \%$ Seduhan Kopi Robusta (SKR)

\section{Materi Dan AlatPenelitian}

Materi yang digunakan pada penelitian ini adalah susu kambing segar yang diperoleh dari peternakan Agribisinis As-Salam Kota Tasikmalaya Jawa Barat, grain kefir dari Milky Way Kota Bogor, dan kopi Robusta dari Shelter Galunggung Kab. Tasikmalaya Jawa Barat. Penelitian ini dilaksanakan di laboratorium peternakan (Universitas PerjuanganTasikmalaya) dan Laboratorium sentral ( Universitas padjadjaran). Peralatan yang digunakan gelas ukur $100 \mathrm{ml}$, gelas beaker $500 \mathrm{ml}$, Erlenmeyer $500 \mathrm{ml}$,cawan petri, mikropipet 10-100 ul, pH meter, buret merk duran, toples plastik, kain saring, timbangan analitik, hotplate, magnetic stairer $5 \mathrm{~cm}$, spektrofotometri, dan lemari es.

\section{Prosedur Penelitian \\ Urutan Kerja Penelitian}

Prosedur pembuatan biakan kefir menggunakan 1 liter susu kambing yang di pasteurisasi menggunaknmetode (HTST) High Tempetarure Long Time pada susu dan waktu (72oC, 15 menit), diamkan sampai menyerupai susu ruangan. Pada pembuatan (SKR) dengan menggunakan teknik simphon yaitu dengan cara memanfaatkan tekanan uap yang nantinya akan masuk ke pipa kecil (funel) yang mengalirkan air panas kekontainer kopi (Gardjito dan Rahardian, 2012) dengan suhu 92oc sesuai dengan standar Specialty Coffee Assosiation Of America (SCAA) kemudian ditambahkan $10 \%$ grain kefir yang didiamkan selama 24 jam pada susu ruang.

\section{Pengujian parameter}

Pengujian $\mathrm{pH}$ diuku rmenggunakan $\mathrm{pH}$ meter yang sudah dikabrasi dengan buffer $\mathrm{pH} 4$ dan 7 , prosedur pengukuran $\mathrm{pH}$ yaitu dengan mengatur suhu sampel dahulu kemudian baru mengatur suhu $\mathrm{pH}$ meter pada suhu terukur. $\mathrm{pH}$ meter dinyalakan dan dibiarkan supaya stabil selama 15-30 menit, elektroda dibilas menggunakan aquades lalu keringkan pakai tisu dan elektroda dicelupkan pada sampel sampai mendapatkan hasil pembacaan skala yang stabil (Azizahet al 2013). Pada pengujian kadar fenolat dengan menggunakan analisis kimia yang berdasarkan perbedaan intensitas warna larutan dan warna standar, pada metode kolometri menggunakan reagen FolinCiocalceu merupakan reaksi reduksi dan oksidasi. Senyawa tersebut berwarna biru yang dapat diukur menggunakan cahaya Spektrofotometri UV-Vis (Tursimanet al., 2012), dimana penyerapan maksimal gugus kromofor tergantung pada larutan alkali dan kosentrasi senyawa fenolat (Brainskiet al., 2013). Pengujian antioksida nmenggunak anmetode DPPH (2,2-difenil-1- pikrihidrazil). Antioksidan hidrosat kefir susu kambing diuji dengan mengukur kemampuan menetralisir radikal bebas DPPH, warna pada radikal bebas DPPH akan berkurang dengan kehadiran antioksidan yang mendonorokan ion hidrogen, absorbansi sampel akan diukur pada panjang gelombang $540 \mathrm{~nm}$ dan aktivitas antioksidan dihitung berdasarkan persentase dari selisih absorban dan ektrak terhadaap daya hambat Thaiponget al., (2006) dan Clarke et al.,(2013).

\section{HASIL DAN PEMBAHASAN}

\section{pH}

$\mathrm{pH}$ diiuji untuk mengetahui derajat keasaman dan kebasaan pada setiap olahan, nilai $\mathrm{pH}$ juga berpengaruh atas pertumbuhan mikroorganisme, perubahan temperatur dan struktur kimia suatu senyawa pada kandungan olahan. Hasil pengujian nilai $\mathrm{pH}$ kefir susu kambing yang ditambahkan seduhan kopi robusta menunjukan rasio yang singnifikan berpengaruh nyata $(p<0,05)$, dengan umumnya pH kefir 4,2 sampai 4,6. ( Fanworth, 2008)

Tabel1. Nilai pH Kefir

\begin{tabular}{ll}
\hline Perlakuan & Nilai $\mathrm{pH}$ \\
\hline P0 & $4.16 \pm 0,057^{\mathrm{a}}$ \\
P1 & $4,36 \pm 0,036^{\mathrm{ab}}$ \\
P2 & $4,42 \pm 0,055^{\mathrm{b}}$ \\
P3 & $4,41 \pm 0,073^{\mathrm{ab}}$ \\
P4 & $4,35 \pm 0,18^{\mathrm{ab}}$ \\
\hline
\end{tabular}

Keterangan : angka - angka yang diikuti superskrip huruf kecil yang berbeda dan menunjukan berbeda nyata $(\mathrm{p}<0,05)$. Maka pada perlakuan P0 sampai dengan P4 dengan 
rataan $\mathrm{pH}$ pada kefir tersebut 4,16 hingga

\begin{tabular}{llll}
\hline $\begin{array}{l}\text { Sampe } \\
\text { l }\end{array}$ & $\begin{array}{l}\text { Pengulang } \\
\text { an ke-1 }\end{array}$ & $\begin{array}{l}\text { Pengulang } \\
\text { an ke-2 }\end{array}$ & Rata - rata \\
\hline P0 & 11754.9091 & 12012.5682 & 11883.7386 \\
P1 & 3503.6479 & 3345.1986 & 3424.4233 \\
P2 & 1501.2975 & 1466.0892 & 1483.6933 \\
P3 & 843.9819 & 827.1421 & 835.5620 \\
P4 & 574.2842 & 534.4047 & 554.3444 \\
\hline
\end{tabular}

4,42, hasil ini masih bias dinyatakan normal karena sesuai dengan peryataan (Fanowrth, 2008). Adapun standar $\mathrm{pH}$ susu fermentasi berdasarkan (Australia Food Standard code 2.5.3. 2015) yaitu maksimal 4,5. Penambahan SKR pada proses fermentasi susu kambing menghasilkan hasil yang signifikan menunjukan pengaruh yang nyata $(\mathrm{P}<0,05)$ terhadap nilai $\mathrm{pH}$ susu kambing. Dengan beda penambahan pada setiap perlakuan konsetrasi $0 \%, 5 \%, 10 \% 15 \%$, dan $20 \%$. Namun hasil tertinggi pada P2 dengan penambahan $10 \%$ yaitu : 4,42 + 0,05, sedangkan nilai $\mathrm{pH}$ terendah diperoleh pada P0 tanpa penambahan SKR, yaitu sebesar $4,16+0,057$. Peningkatan nilai $\mathrm{pH}$ pada kefir susu kambing yang ditambahkan seduhan kopi robusta sangat dipengaruhi oleh nilai $\mathrm{pH}$ dari kopi robusta. Kopi robusta memiliki nilaipH lebih tinggi dibandingkan dengan kopi arabika dengan rasio perbedaan 5,47 dan 5,01 (Ni Nyoman et al.,2017).

Maka dengan itu proses fermentasi susu kambing yang ditambahkan seduhan kopi rosusta menunjukan hasil $\mathrm{pH}$ yang semakin meningkat saat persentase penambahan konsentrasi lebih tinggi. Hal ini sesuai dengan hasil penelitian adanya penurunan pertumbuhan bakteri asam laktat saat jumlah seduhankopi robusta yang ditambahkan lebih meningkat (Rifai, 2020). Sehingga asam laktat yang dihasilkan bakteri asam laktat semakin sedikit yang menyebabkan peningkatan nilai $\mathrm{pH}$ pada kefir susu kambing.

\section{Kadar polifenoltotal}

Kadar fenolat total yang terkandung pada sampel memiliki hasil yang akan berbanding lurus dengan aktivitas antioksidan, dan diduga jika adanya peningkatan total fenol maka akan ada aktivitas antioksidan yang sedang berlangsung (Topiah et al,.2014). Karena fenol berperan sebagai kontibutor utama dalam aktivitas antioksidan (Fitri et al,.2008) Maka pengujian total fenol ini sangat penting untuk mengatahui aktivitas antioksidan pada kefir susu kambing yang bertujuan menjadi minuman fungsional.

Tabel 2. Kadar PolifenolTotal

\begin{tabular}{ll}
\hline Perlakuan & Fenolat $(\mathrm{mg} / \mathrm{L})$ \\
\hline P0 & 120.6347 \\
P1 & 225.9424 \\
P2 & 355.2454 \\
P3 & 641.6232 \\
P4 & 684.4686 \\
Standar Deviasi & 249.7460 \\
\hline
\end{tabular}

Tabel 2. Menunjukan hasil analisis kadar polifenol pada kefir susu kambing yang ditambahkan seduhan kopi robusta, susu adalah medium paling cocok sebagai tempat pertumbuhan bakteri Lactobacillus bulgaricus dan khamir candida kefir, karena kedua bakteri ini dapat memfermentasi glukosa (Supriyono,2008). Adanya polifenol pada kefir dihasilkan terutama oleh khamir candida kefir, didapatkan hasil analisis diatas dengan algoritma yang naik disebabkan penambahan konsentrasi seduhan kopi robusta dengan melibatkan juga system oksidasi. Semakin banyak penambahan seduhan kopi robusta maka akan semakin meningkat kadar polifenol. Proses fermentasi juga melibatkan banyak tipe reaksi kimia contohny aoksidasi (Rahman 1989), yang menyebabkan hasil polifenol pada analisis ini meningkat saat ditambahkan seduhan kopi robusta. Naiknya polifenol pada kefir juga kemungkinan terjadi karena turunya kondisi asam yang bertolak belakang dengan penelitian sebelumnya (Supriyono,2008), yang menjelaskan bahwa fenolat total menurun dikarenakan kondisi asam yang naik. Disebabkan Karena semakin asam akan semakin banyak jumlah strater yang menyebabkan polifenol menjadi antioksidan melawan reaksi oksidasi tersebut.

Produksi optimal kadar polifenol pada perlakuan P4 karena memiliki kondisi asam yang sesuai dan jumlah starter yang cukup, karena pada penelitian sebelumnya menjelaskan bahwa pembentukan senyawa fenol melalui dekarboksilasi asam mempunyai rentang $\mathrm{pH}$ 4-5 (Yang et al,.2004). Maka semakin rendahnya 
pH karena semakin tingginya glukosa terjadi pengendapan protein dengan berlanjutnya proses fermentasi terjadi peningkatan polifenol atau protein (Shahidi and Nadck, 1995), dan diharapkan dengan tingginya kadar polifenol berdampak juga terhadap aktivitas antioksidan pada kefir susu kambing yang ditambahkanseduhan kopi robusta. Hasil ini pun yang diharapkan atau sesuaidengan hipotesis sebelumnya dengan tujuan menghasikan minuman fungsional atau nutraceutical.

\section{AktivitasAntioksidan}

Analisis aktivivtas antioksidan ini dilakukan setelah fermentasi, antioksidan merupakan senyawa bioaktif yang sangat bermanfaat bagi tubuh dalam kesehatan dan penuaan. Karena sifatnya yang dapat menangakal radikal bebas dalam tubuh maupun diperoleh dari makanan, polusi udara dan cemaran sinar matahari.

\section{Tabel 3. AktivitasAntioksidan}

\begin{tabular}{llll}
\hline Sampel & $\begin{array}{l}\text { Pengulangan } \\
\text { ke-1 }\end{array}$ & $\begin{array}{l}\text { Pengulangan } \\
\text { ke-2 }\end{array}$ & Rata - rata \\
\hline P0 & 11754.9091 & 12012.5682 & 11883.7386 \\
P1 & 3503.6479 & 3345.1986 & 3424.4233 \\
P2 & 1501.2975 & 1466.0892 & 1483.6933 \\
P3 & 843.9819 & 827.1421 & 835.5620 \\
P4 & 574.2842 & 534.4047 & 554.3444 \\
\end{tabular}

Berdasarkan hasil analisis menggunakan metode DPPH, memperoleh hasil yang ada pada tabel 3. Pada data diatas mendapatkan hasil bahwa semakin tinggi penambahan seduhan kopi robusta mempengaruhi peningkatan aktivitas antioksidan pada kefir. Aktivitas antioksidan yang paling rendah ada pada perlakuan P0 tanpa penambahan seduhan kopi robusta atau (kontrol), sedangkan aktivitas tertinggi ada pada perlakuan P4 dengan penambahan $20 \%$.

Untuk menghambat IC50 dengan menggunakan P0 harus membutuhkan 11883.7386 sedangkan jika menggunakan perlakuan P4 hanya dibutuhkan 554.3444 saja. Maka perbandingan peningkatan aktivitas antioksidan pada perlakuan P0 (kontrol) dengan perlakuan maksimal pada P4 adalah 91\%. Hal ini menunjukan bahwa kandungan kopi berupa monosakarida menurut (Mulato dan Suharyanto,2012)

$$
\text { Dapat menyeimbangakan dengan }
$$

kandungan pada susu kambing serta tempat starter berkembang biak. Dengan kedua bahan mengandung antioksidan seperti yang sudah dijelaskan di awal pada latar belakang, maka pada penelitian in imenghasilkan hasil analisis yang sesuai dengan tujuan. Sesuai dengan penelitian sebelumnya (Siagian, 2002) menyatakan bahwa kombinasi antara antioksidan akan memberikan perlindungan yang lebih terhadap oksidasi dibandingkan satu jenis antioksidan saja.

Peningkatan aktivitas antioksidan juga dapat diduga karena adanya aktivitas bakteri asam laktat, kareana selama fermentasi senyawa - senyawa yang dapat menstabilkan dan menaikan aktivitas antioksidan seperti asam laktat, asam asetat, asam sitrat, dan asam suksinat (Primurdia, 2014). Peningkatan aktivitas antioksidan kefir susu kambing dengan penambahan sedduhan kopi robusta ini kemungkinan juga disebabkan cukup tingginya kandungan antioksidan asam khlorogenat dalam kopi robusta. sehingga semakin besar penambahan SKR akan meningkatkan aktivitas Antioksidan. Diketahui pada penelitian sebelumnya (Rifai, 2020) menjelaskan bahwa semakin banyak penambahan seduhan kopi robusta maka aktivitas bakteri asam laktat akan meningkat. Maka dapat disimpulkan bahwa kolerasi antara $\mathrm{pH}$, Bakteri asam laktat, dan kadar fenolat sangat nyata dengan aktivitas antioksidan. Zuhra et al,.2008 menyatakan bahwa antioksidan yang kuat adalah pada angka 50-100 sedangkan yang sedang pada angka 100150, dan rendah jika 151-200. Aktivitas antioksidan yang dinyatakan pada IC50 akan dinyatakan tinggi jika hasilnya menunjukan kecil. Dengan demikian kadar antioksidan pada susu kambing yang sudah ditambahkan seduhan kopi robusta lalu difermentasi lebih tinggi dibandingkan hanya susu kambing yang difermentasi..

\section{KESIMPULAN}

Seduhan kopi robusta sangat berpengaruh nyata terhadap nilai $\mathrm{pH}$, kadar fenolat total dan aktivitas antioksidan. Perlakuan terbaik atau paling optimal di penelitian ini ada pada P4 
dengannilai $\mathrm{pH}$ yang didapat $(4,35)$, fenolat total $(684,46)$ dan aktivitasantioksidandengan rata- rata IC50(ppm) (554, 34). Yang jelas berbeda nyata dengan $\mathrm{P} 0$ (kontrol).

\section{REFERENSI}

Dinas Peternakan dan Perikanan Kabupaten Chayati, Ichda. 2014. Bahan Ajar PengujianBahanPangan. Yogyakarta: Universitas Negeri Yogyakarta.

Comparison of Antioxidant Activities of Hydrolysates of Domestic and Imported Skim Milk Powders Treated with Papain. Korean Journal. Food Science. An. 35( 3):360-369.

Ersan, L.Y., Ozcan, T., Bayizit, A.A. dan Sahin, S. (2016). The Antioxidative

Eun Ha, G., CO. Ki, HG. Sung, HJ. Sang, B. Park, \& S. Jeong. 2015.

Gardjito, Murdijati dan Rahadian D.A. 2011. Kopi. Kanisius. Yogyakarta.]

Guven, A., dan Gulmez, M. (2003). The effect of kefir on the activities of GSHPx, GST, CAT, GSH and LPO levels in carbon tetrachloride-induced mice tissues.

Haenlein GEW 2004 Goat milk ini human nutrition. Small ruminant Res : 51, 155163.

Journalof Veterinary Medicine, 50, 412-416.

Kusumaningtyas, E., R. Widiastuti, HD. Kusumaningrum, \& MT. Suhartono 2015. Antimicrobial and antioxidative activities of peptides from goat milk hydrolyzed with various protease. Journal Animal Veterinary Science. 20(3):175-183.

Kusumaningtyas, E., R. Widiastuti, HD. Kusumaningrum, \&TM.Suhartono. 2016. Aktivitasantibakteri dan antioksidanhidrolisathasilhidrolisis protein susukambingdenganekstrakkasarbromeli n. JurnalTeknologiIndustriPangan. 26(2):
179-188. doi: 10.6066/jtip.2015.26.2.179.

Kunaepah,U.2008. Pengaruh Lama Fermentasi dan Konsentrasi Glukosa terhadap Aktivitas Antibakteri, Polifenol Total dan Mutu Kimia Kefir Susu Kacang Merah. Tesis.Universitas Diponegoro, Semarang.

Nurliyani. (2012). Penanganan dan PengolahanSususecaraSederhana. Yogyakarta : PT Citra AjiPratama.

Nurliyani, Sadewa, A. H., \&Sunarti. (2015). Kefir properties prepared withgoat milk and black rice (Oryza sativa L.) extract and its influence on the improvement of pancreatic [beta]-cells in diabetic rats. Emirates Journal of Food and Agriculture, 27(10), 727.

Oktaviani, S. D., Sabikis, S., \& Hartanti, D. (2011). Identifikasi Etanol Hasil Fermentasi Sente (Alocasia Macrorrizha (L.) g. don), Sente Wulung (Alocasia Indica (Lour.) Koch) Dan Kimpul (Xhantosoma Nigrum (Vell.) Mansf). Pharmacy: Jurnal Farmasi Indonesia, 8(01).

Osuntoki, A., \& Korie, I. (2010). Antioxidant activity of whey from milk fermented with Lactobacillus species isolated from Nigerian fermented foods. Food Technology and Biotechnology, 48(4), 505511.

Pratt, D. (1992). Natural antioxidants from plant material: ACS Publications.

Richana, N. 2011. Bioetanol: Bahan Baku, Teknologi, Produksi dan Pengendalian Mutu. Penerbit Nuansa, Bandung.

Thaipong K., U. Boonprakob, K. Crosby, L. Cisneros -Zevallos, DH. \& Byrne. 2006. Comparison of ABTS, DPPH, FRAP, and ORAC assays for estimation antioxidant activity from guava fruit extracts. Journal Food Compos Anals. 19: 669-676. doi : 10.1016/j.jfca.2006.01.003.

Toripah, S, S. A, Jemmy, dan W, Frenly. 2014. Aktivitasantioksidan dan kandungan total fenolikekstrakdaunkelor (Moringa Oleifera Lam.). Jurnal ilmiahFarmasi. Manado. 3 ( 4 ) : 